Chiara Preite, Analyse de l'organisation énonciative des arrêts de la Cour de justice et du Tribunal de Première Instance des communautés européennes

\title{
Sara Vecchiato
}

\section{(2) OpenEdition \\ 1 Journals}

Édition électronique

URL : http://journals.openedition.org/studifrancesi/31002

DOI : $10.4000 /$ studifrancesi.31002

ISSN : 2421-5856

Éditeur

Rosenberg \& Sellier

Édition imprimée

Date de publication : 1 avril 2006

Pagination : 214

ISSN : 0039-2944

\section{Référence électronique}

Sara Vecchiato, «Chiara Preite, Analyse de l'organisation énonciative des arrêts de la Cour de justice et du Tribunal de Première Instance des communautés européennes », Studi Francesi [En ligne], 148 (XLX | I) | 2006, mis en ligne le 30 novembre 2015, consulté le 22 avril 2021. URL : http://

journals.openedition.org/studifrancesi/31002; DOI : https://doi.org/10.4000/studifrancesi.31002

Ce document a été généré automatiquement le 22 avril 2021.

\section{cc) $($ ) $\ominus$}

Studi Francesi è distribuita con Licenza Creative Commons Attribuzione - Non commerciale - Non opere derivate 4.0 Internazionale. 


\title{
Chiara Preite, Analyse de
} l'organisation énonciative des arrêts de la Cour de justice et du Tribunal de Première Instance des communautés européennes

\author{
Sara Vecchiato
}

\section{RÉFÉRENCE}

CHIARA PREITE, Analyse de l'organisation énonciative des arrêts de la Cour de justice et du Tribunal de Première Instance des communautés européennes, « Corela - Cognition, Représentation, Langage », Numéros spéciaux, Colloque AFLS, 2005.

1 Accessible en ligne à l'URL: http://univ-poitiers.fr/corela/document.php?id=180 [Lien non disponible : 16/9/2016].

2 Cet article de Chiara Preite constitue l'une des contributions au colloque international que l'« Association for French Language Studies » a organisé en 2003, dont les actes ont paru sous le titre "Le français aujourd'hui: problèmes et méthodes». Dans sa contribution, axée sur le domaine de l'analyse du discours, l'auteur s'attache à cerner les démarches énonciatives des arrêts rendus par la Cour de Justice et le Tribunal de Première Instance des communautés européennes. En partant d'un corpus d'une quarantaine d'arrêts, Chiara Preite se focalise d'abord sur les choix morphosyntaxiques (emploi des pronoms personnels et des verbes) et lexicaux du texte qui instaurent un régime d'impersonnalité et un système de politesse linguistique. Cependant, comme le montre l'auteur, cette impersonnalité, recherchée aussi bien pour des raisons sociolinguistiques qu'interactionnelles, est estompée, voire démentie, par la structure polyphonique et très hétérogène du discours. Une analyse pointue de l'utilisation des 
déictiques, spatiaux et temporels, permet en outre d'étudier l'affirmation de la nature performative de l'arrêt au moment de sa lecture, et dans le même temps la négation de la contingence. L'arrêt est censé être générique, non contingent, puisqu'il est destiné à demeurer un exemple juridictionnel.

3 Outre la réflexion théorique, les retombées didactiques d'une analyse de ce genre sont considérées également, en termes de compétences à développer chez des étudiants en droit italophones. 